\title{
BIOETHANOL FERMENTATION FROM NON-TREATED AND PRETREATED CORN STOVER USING ASPERGILLUS ORYZAE
}

\author{
S. K. Masud Hossain* \\ Received 11 December 2010; received in revised form 13 August 2011
}

\begin{abstract}
A comparison was studied for non-treated and pretreated corn stover with dilute alkaline peroxide and dilute acid treatment respectively for bioethanol production by simultaneous saccharification and fermentation (SSF) process in a continuous stirred batch bioreactor using fungi Aspergillus oryzae. The optimum parameters for bioethanol fermentation were: time, $48 \mathrm{~h} ; \mathrm{pH}, 6.0$; temperature, $50^{\circ} \mathrm{C}$; stirring speed, $35 \mathrm{rpm}$; and corn stover loading, 35 $\mathrm{g} / \mathrm{L}$. The maximum concentration of bioethanol at optimum fermentation process parameters were $0.762 \mathrm{~g} / \mathrm{g}, 0.799 \mathrm{~g} / \mathrm{g}$ and $0.819 \mathrm{~g} / \mathrm{g}$ for non-treated, dilute acid and dilute alkaline peroxide pretreated corn stover respectively. Maximum yields of bioethanol were $0.399 \mathrm{~g} / \mathrm{L} . \mathrm{h}, 0.420 \mathrm{~g} / \mathrm{L} . \mathrm{h}$ and $0.431 \mathrm{~g} / \mathrm{L}$.h of corn stover at optimum parameters for non-treated, dilute acid and dilute alkaline peroxide pretreated corn stover respectively. The sp. growth rate $(\mu)$ were $5.30 \mathrm{~s}^{-1}$, $5.54 \mathrm{~s}^{-1}$, and $5.93 \mathrm{~s}^{-1}$ and maximum sp. growth rate $\left(\mu_{\max }\right)$ were $10.60 \mathrm{~s}^{-1}, 11.08 \mathrm{~s}^{-1}$ and 11.86 $\mathrm{s}^{-1}$ using Monod model for non-treated, dilute acid and dilute alkaline peroxide pretreated corn stover respectively. The Monod parameter $\left(\mathrm{K}_{\mathrm{s}}\right)$ were $33.87 \mathrm{~g} / \mathrm{L}, 34.21 \mathrm{~g} / \mathrm{L}$ and $34.85 \mathrm{~g} / \mathrm{L}$ for non-treated, dilute acid and dilute alkaline peroxide pretreated corn stover respectively. The sp. enzyme activity $(v)$ were $1192 \mathrm{~min}^{-1}, 1463 \mathrm{~min}^{-1}$ and $1559 \mathrm{~min}^{-1}$ and maximum sp. growth rate $(v \max )$ were $2384 \mathrm{~min}^{-1}, 2926 \mathrm{~min}^{-1}$ and $3118 \mathrm{~min}^{-1}$ using Michaelis-Menten enzyme kinetic model for non-treated, dilute acid and dilute alkaline peroxide pretreated corn stover respectively. The Michaelis-Menten parameter $\left(\mathrm{K}_{\mathrm{m}}\right)$ were $34.42 \mathrm{~g} / \mathrm{L}, 34.63 \mathrm{~g} / \mathrm{L}$ and $34.85 \mathrm{~g} / \mathrm{L}$ for non-treated, dilute acid and dilute alkaline peroxide pretreated corn stover respectively. The first order rate constants $(\mathrm{k})$ were $0.014 \mathrm{~h}^{-1}, 0.016 \mathrm{~h}^{-1}$ and $0.019 \mathrm{~h}^{-1}$ for non-treated, dilute acid and dilute alkaline peroxide pretreated corn stover for continuous stirred batch bioreactor respectively.
\end{abstract}

Keywords: Biofuel; Bioethanol; Corn Stover; Optimum; Parameters; Saccharification.

\section{INTRODUCTION}

The 20th century was marked by dramatic changes in energy supply. During this period, the dominant energy supply shifted from biomass to coal in about early 20th century, and then shifted from coal to oil in about mid 20th century. Meanwhile, during the past 150 years, human activities have caused a dramatic increase in the emission of greenhouse gases, e.g. $\mathrm{CO}_{2}$,

*To whom all correspondence should be addressed. (e-mail:skmhossain@yahoo.co.in) which has led to changes in the equilibrium of the earth's atmosphere. Therefore, the increased concern for the security of the oil supply and the negative impact of fossil fuels on the environment has put pressure on society to find renewable fuel alternatives. The use of bioethanol, the biofuel of the future, as a source of energy would be more than just complementing for solar, wind, and

(c) Bangladesh Uni. of Engg. \& Tech. 33 
other intermittent renewable energy sources in the long run. Now, bioethanol has already been introduced on a large scale in many countries [1], and it is expected to be one of the dominating renewable biofuel in the transport sector in near future. Compared with simlpe gasoline, ethanol has a higher octane number (96-113) that reduces the need for toxic, octane enhancing additives. It is also a provider of oxygen, which helps to reduce the emission of carbon monoxide $(\mathrm{CO})$, nitrogen oxides $\left(\mathrm{NO}_{\mathrm{x}}\right)$, noncombusted hydrocarbon, and reduces the exhaust of volatile organic compounds (VOC) after combustion. In addition, ethanol is about $15 \%$ more efficient than gasoline in optimized spark-ignition engines. Ethanol can be blended with petrol and used as neat ethanol. Ethanol also reduces smog formation because of its low volatility and photochemical reactivity [1].

Today bioethanol is produced from sugar or starchy raw materials that are relatively expensive. To lower the production cost of bioethanol, the cost of the raw material must be reduced and the production process made more efficient. Bioethanol is made biologically from a variety of lignocellulosic biomass sources such as agricultural and forestry residues, grasses, and fast growing wood is widely recognized as a unique sustainable liquid transportation fuel with powerful economic, environmental, and strategic attributes. The production of bioethanol from lignocellulosic biomass offers a more favorable trade balance, enhanced energy security, and a major new crop for a depressed agricultural economy [2-14]. Different fermentation organisms among bacteria, yeasts, and fungi (natural as well as recombinant) are reviewed with emphasis on their performance in lignocellulosics. There are mainly two processes involved in the conversion: hydrolysis of cellulose in the lignocellulosic materials to produce reducing sugars, and fermentation of the sugars to ethanol. For the realization of the bioethanol production from lignocellulosic materials, the fermentation step has to be integrated with the rest of the process. The simultaneous saccharification and fermentation (SSF) process is a favored option for conversion of the lignocellulosics because it provides enhanced rates, yields, and concentrations of bioethanol. The SSF process effectively removes glucose, which is an inhibitor to cellulase activity, thus increasing the yield and rate of cellulose hydrolysis. Pretreatment of lignocellulosic materials to remove lignin and hemicellulose can significantly enhance celluloses content and the hydrolysis of celluloses [2-16]. In recent years, progress has been made in developing more effective pretreatment and hydrolysis processes leading to higher yield of sugars and bioethanol from agro-residues [17-22].

The comparison studies were undertaken for aerobic bioethanol production from non-treated and pretreated lignocellulosic agro-residue corn stover in a continuous stirred batch bioreactor using fungi Aspergillus oryzae. Attempts were made to optimize process parameters like fermentation time, $\mathrm{pH}$, temperature, stirring speed (rpm) and corn stover (non-treated and pretreated) loading for maximum bioethanol production. The specific growth rate $(\mu)$ and maximum sp. growth rate $(\mu$ $\max$ ) of fungi Aspergillus oryzae were determined by Monod growth model. Cellulase enzyme activity was also assayed for non-treated and pretreated corn stover loading and plotted using Michaelis-Menten enzyme kinetic model. The specific enzyme activity $(v)$ and maximum sp. enzyme activity $\left(v_{\max }\right)$ of fungi Aspergillus oryzae were determined using Michaelis-Menten model. Monod parameter $\left(\mathrm{K}_{\mathrm{s}}\right)$ and 
Michaelis-Menten kinetic parameter $\left(\mathrm{K}_{\mathrm{m}}\right)$ were determined for non-treated and pretreated corn stover. The rate constants (k) were determined for non-treated, dilute acid and dilute alkaline peroxide pretreated corn stover in continuous stirred batch bioreactor respectively.

\section{EXPERIMENTAL}

\section{Collection of Fungi and Culture Preparation}

The freeze-dried (lyophilized) fungi Aspergillus oryzae (MTCC 1847) was collected from Microbial Type Culture Collection and Gene Bank, Institute of Microbial Technology, Chandigarh, India, and was stored in a freeze at $-4^{\circ} \mathrm{C}$. The slant culture was aseptically prepared in growth medium of Czapek yeast extract agar -CYA medium (Czapek concentrate $10.0 \mathrm{~mL} ; \mathrm{KH}_{2} \mathrm{PO}_{4} 1.0 \mathrm{~g}$; yeast extract $5.0 \mathrm{~g}$; sucrose $30.0 \mathrm{~g}$; agar $15.0 \mathrm{~g}$; distilled water 1.0 L). Czapek concentrate contains: $\mathrm{NaNO}_{3}-30.0 \mathrm{~g}, \mathrm{KCl}-5.0 \mathrm{~g}, \mathrm{MnSO}_{4} .7 \mathrm{H}_{2} \mathrm{O}-$ $0.05 \mathrm{~g}, \mathrm{FeSO}_{4} .7 \mathrm{H}_{2} \mathrm{O}-0.10 \mathrm{~g}$, distilled water $100 \mathrm{~mL}$. It can be stored without sterilization. The precipitate of $\mathrm{Fe}(\mathrm{OH})_{3}$ can be resuspended by shaking well before use. The slant culture were kept for a period of 7 days at $25^{\circ} \mathrm{C}$ in an incubator for sufficient sporulation and spore crops were then harvested by washing the fully-grown slants with sterile distilled water and transferred to suspension culture media in $250 \mathrm{~mL}$ Erlenmeyer flasks. It was again kept in an incubator maintained at $25^{\circ} \mathrm{C}$ for 7 days for proper growth. The suspension culture was filtered through several layers of sterile absorbent cotton and cultured again in the same suspension medium. The final fungal population was arbitrarily chosen as $5.6 \times 10$ ${ }^{5}$ numbers of cells per $\mathrm{mL}$ of the suspension culture. The same fungal suspension culture was used for the present studies. The following constituents are used for suspension culture media [23-25] preparation per liter: $\mathrm{KH}_{2} \mathrm{PO}_{4}$ - $20 \mathrm{~g}$, $\mathrm{MgSO}_{4} .7 \mathrm{H}_{2} \mathrm{O}-5.0 \mathrm{~g}, \mathrm{CaCl}_{2}-1.0 \mathrm{~g}, \mathrm{MnSO}_{4}$. $7 \mathrm{H}_{2} \mathrm{O}-0.05 \mathrm{~g}, \mathrm{FeSO}_{4} .7 \mathrm{H}_{2} \mathrm{O}-0.10 \mathrm{~g}, \mathrm{CaCl}_{2}$. $6 \mathrm{H}_{2} \mathrm{O}-0.10 \mathrm{~g}$, AlK $\left(\mathrm{SO}_{4}\right)_{2} .12 \mathrm{H}_{2} \mathrm{O}-0.01 \mathrm{~g}$, $\mathrm{Na}_{2} \mathrm{MoO}_{4} \cdot 2 \cdot \mathrm{H}_{2} \mathrm{O}-0.01 \mathrm{~g}$.

\section{Collection and Analysis of Corn Stover}

Corn stover was collected from agricultural farm and stored in laboratory at atmospheric pressure and room temperature. Samples were cut into useable sizes, dried in shadow and stored for studies. Samples were grinded ( 25 mesh size) in a grinder. The physico-chemical properties of raw material corn stover are: lignin, $21.36 \%$ $(\mathrm{w} / \mathrm{w}) ; \quad$ celluloses, $\quad 48.67 \% \quad(\mathrm{w} / \mathrm{w})$; hemicellulose, $19.35 \%(\mathrm{w} / \mathrm{w})$; and silica $3.23 \%(\mathrm{w} / \mathrm{w})$.

\section{Pretreatment of Corn Stover}

The cellulose content of corn stover is one of the most important factors for bioethanol production from lignocellulosic agro-residue. To increase the cellulose content of corn stover and bioethanol yield in SSF process, a pretreatment of corn stover with dilute alkaline peroxide $(7.50 \%$ v/v $\mathrm{H}_{2} \mathrm{O}_{2} ; \mathrm{pH} 11.5$; temperature $35^{\circ} \mathrm{C}$; time $6 \mathrm{~h}$ ) and dilute acid treatment (dilute $\mathrm{H}_{2} \mathrm{SO}_{4}$ $0.75 \%, \mathrm{v} / \mathrm{v}$; temperature $55^{\circ} \mathrm{C}$; time $6 \mathrm{~h}$ ) were studied. After the treatment, the cellulose content in corn stover increased to $68.79 \%(\mathrm{w} / \mathrm{w})$ for dilute alkaline peroxide and $65.25 \%(\mathrm{w} / \mathrm{w})$ for dilute acid treatment respectively.

\section{General Method}

Bioethanol fermentation was carried out in glass bioreactor $(3 \mathrm{~L})$ containing $(25$ mesh) sized of corn stover $(25 \mathrm{~g} / \mathrm{L})$ to be digested for bioethanol fermentation. Suspension fungal culture $(1 \mathrm{~L})$ as inoculum was added to the raw material. Suspension 
culture media (1 L) were added to the contents. The initial $\mathrm{pH}$ (4.5) of content was maintained by using $0.1 \mathrm{~N} \mathrm{H}_{2} \mathrm{SO}_{4}$ and/or 1 $\mathrm{M} \mathrm{CaCO}_{3}$ slurry. The temperature of the bioreactor was maintained at $35^{\circ} \mathrm{C}$ by means of heating coil fitted with off-on temperature controller. The temperature of bioreactor was measured by a thermocouple. The stirring speed was maintained at $20 \mathrm{rpm}$ with a stirrer in the bioreactor. The methods were also repeated for dilute acid and alkaline peroxide pretreated corn stover. Specific gravity of fermented bioethanol was determined by gravimetric method and it was compared with standard table for conversion into concentration $(\mathrm{g} / \mathrm{L})$.

Effects of Fermentation Time, pH, Temperature, Shaking Speed and Corn Stover Loading

The general method was repeated for various fermentation times. The concentrations and yields of bioethanol were determined (Figure 1 and 2) on a regular interval of time at 12, 24, 36, 48, and $60 \mathrm{~h}$ of digestion time respectively. The general method was repeated for various $\mathrm{pH}$ for optimization. The concentrations and yields of bioethanol were determined (Figure 3 and 4) at optimum time $(48 \mathrm{~h})$ for various $\mathrm{pH}$ of 5, 5.5, 6.0 and 6.5 respectively. The general method was repeated for different temperatures. The concentrations and yields of bioethanol were determined (Figure 5 and 6 ) at optimum time (48 h), and optimum $\mathrm{pH}$ (6.0) for various temperatures of 40, 45, 50 and $55{ }^{\circ} \mathrm{C}$ respectively. The general method was repeated for various stirring speed. The concentrations and yields of bioethanol were determined (Figure 7 and 8) at optimum time (48 h), optimum $\mathrm{pH}(6.0)$ and optimum temperature $\left(50^{\circ} \mathrm{C}\right)$ for different stirring speed of 20, 25, 30, 35 and $40 \mathrm{rpm}$ respectively. The general method was repeated for different corn stover loading. The concentrations and yields of bioethanol were measured (Figure 9 and 10) at optimum time (48 h), optimum $\mathrm{pH}(6.0)$, optimum temperature $\left(50^{\circ} \mathrm{C}\right)$ and optimum stirring speed (35 rpm) for different loading of corn stover such as 30, 35, 40 and $45 \mathrm{~g} / \mathrm{L}$ respectively.

\section{Luckey Drop Method of Fungal Growth}

Exactly $(0.1 \mathrm{~mL})$ of the fermented mixture was put by using a calibrated medicinal dropper onto a glass slide [26]. A cover slip of known area was placed, avoiding any air bubble. The slide was put under a microscope and measured the width of the high power microscopic field. Suppose the area visible at one time was one micro transects. Now the slide moved from one corner to another counting fungus in each visible microscopic field. It was counted several fields by moving the slide in horizontal and vertical directions. Counting must be quick to avoid drying of the sample. Calculation:

Number of fungi per $\mathrm{mL}=$ (No. of fungi counted in all fields $\times$ Area of cover slip, $\mathrm{mm}^{2}$ )/ (Area of one macroscopic field, $\mathrm{mm}^{2}$ $\times$ No. of field counted $\times$ volume of sample in the cover slip)

\section{Assay of Cellulase}

Fermented solution was filtered and taken $(1.0 \mathrm{~mL})$ in a clean dry test tube containing $4.0 \mathrm{ml}$ of $0.05 \mathrm{M}$ acetic acid of $\mathrm{pH}$ 5.0. It was incubated [22] with shaking for $2 \mathrm{~h}$ at $37^{\circ} \mathrm{C}$. Tubes were removed to an ice bath and allowed the sediment to settle followed by clarification by centrifugation. It was stored in an ice bath. $3.0 \mathrm{~mL}$ glucose reagent (ATP, $0.77 \mu \quad \mu \quad \mathrm{mol} / \mathrm{mL}$; Hexokinase, 1.5 units/mL; NAD, $0.91 \mu$ $\mathrm{mol} / \mathrm{mL}$; Glucose-6-phosphate dehydrogenase, 1.9 units $/ \mathrm{ml}$; and Tris- $\mathrm{HCl}$ buffer of $\mathrm{pH} 7.6 \pm 0.2,0.1 \mathrm{M}$ ) was placed in a cuvette and incubated in 
spectrophotometer set at $340 \mathrm{~nm}$ slide and $25^{\circ} \mathrm{C}$ to achieve temperature equilibration. Absorbance was measured for the mixture at $340 \mathrm{~nm}\left(\mathrm{~A}_{340}\right)$ for $1 \mathrm{~min}$ using UV-Vis Spectrophotometer (M/S Perkin-Elmer, Lambda Bio- 40). $A_{340}$ of the glucose reagent in the cuvette was also recorded. The supernatant $(0.1 \mathrm{~mL})$ was added to each reaction tube and recorded increase in $\mathrm{A}_{340}$ until no further change occurred in $1 \mathrm{~min}$. Final $\mathrm{A}_{340}$ was also recorded. It was compared with blank (without fermented enzyme solution) readings.

\section{Calculation}

Units $/ \mathrm{mL} . \min =\left\{\left(\Delta \mathrm{A}_{340}\right.\right.$ Sample $-\Delta \mathrm{A}_{340}$ Blank $) \times 3.1 \times 180.5\} /(6.22 \times 0.1 \times 2 \times 0.01 \times$ mL enzyme in mixture). Where, $\Delta \mathrm{A}_{340}=$ $\mathrm{A}_{340 \text { Final }}-\mathrm{A}_{340 \text { Initial }}$

\section{Blend Preparation}

Three commonly used plastics such as Polyethylene (PE), Polyvinyl chloride (PVC) and Polyethylene terephthalate (PET) were selected for mixing. These polymers were crushed by using size reduction crusher. The blends of PP/PVC/PET were prepared by using Brabender plasticoder. The mixing time, rotation speed and temperature for the preparation of blend wereas $7 \mathrm{~min}, 80 \mathrm{rpm}$ and $230{ }^{\mathrm{O}} \mathrm{C}$ respectively. Additives were added during processing of blends.

\section{Testing and Characterization}

FTIR spectroscopy technique was executed to characterize the nature of cross linking among the three polymers. The rheological properties were accomplished by melt flow tester (Karg Industritechnik: 3100). Rheological tests were performed according to ASTM D-1238. To observe the morphology of various blends, compression moulded samples wereas sputtered with gold in vacuum. These samples were examined by scanning electron microscope (SEM).

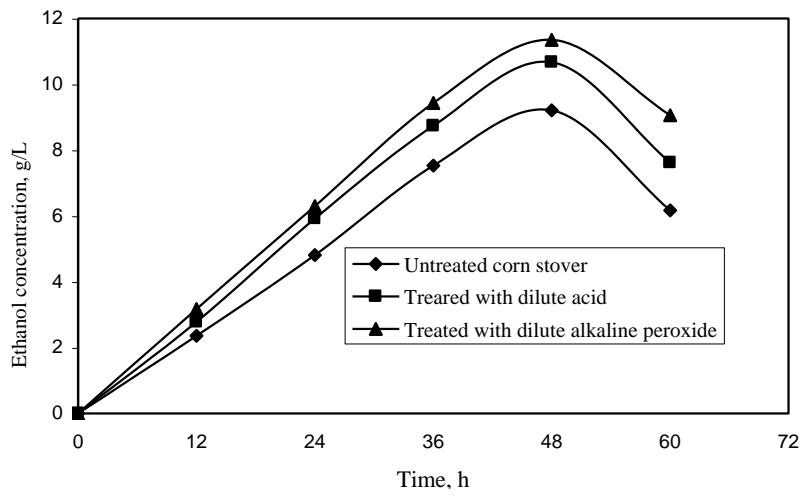

Figure 1: Effect of Formation Time on Concentration

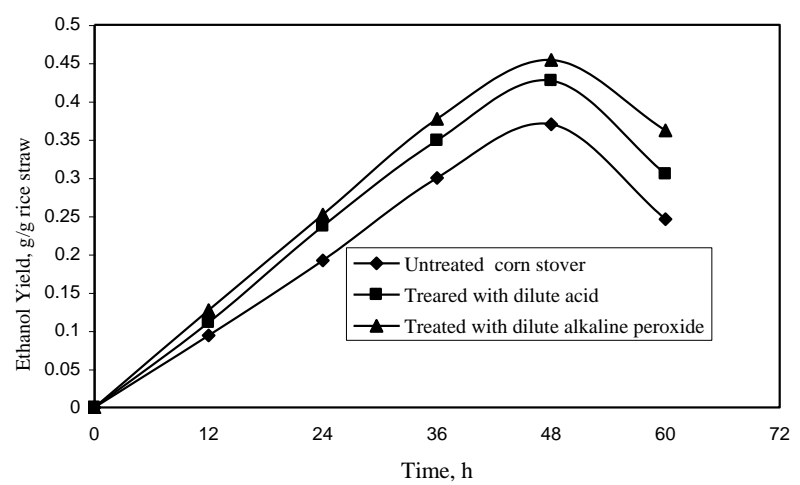

Figure 2: Effect of Formation Time on Ethanol Yield

\section{RESULTS AND DISCUSSION}

\section{Effect of Fermentation Time}

The concentration and yields of bioethanol were proportional to fermentation time. The concentrations and yields of bioethanol increased with increase of time up to $48 \mathrm{~h}$ and then both declined (Figure1 and 2). Yields and concentrations of bioethanol were highest at fermentation time of $48 \mathrm{~h}$. Maximum concentrations of bioethanol were $9.38 \mathrm{~g} / \mathrm{L}, 10.67 \mathrm{~g} / \mathrm{L}$ and $11.35 \mathrm{~g} / \mathrm{L}$ for non-treated, dilute acid and dilute alkaline peroxide pretreated corn stover (Figure 1) at $48 \mathrm{~h}$ of time respectively. Maximum yields of bioethanol were $0.375 \mathrm{~g} / \mathrm{g}, 0.431 \mathrm{~g} / \mathrm{g}$ and $0.459 \mathrm{~g} / \mathrm{g}$ of corn stover at $48 \mathrm{~h}$ of time for non-treated, 
dilute acid and dilute alkaline peroxide pretreated corn stover respectively. Operating time $(48 \mathrm{~h})$ was optimum for bioethanol fermentation of pretreated and non-treated corn stover with fungi Aspergillus oryzae. The maximum bioethanol production were $0.196 \mathrm{~g} / \mathrm{L} \mathrm{h}$, $0.225 \mathrm{~g} / \mathrm{L} \mathrm{h}$ and $0.239 \mathrm{~g} / \mathrm{L} \mathrm{h}$ for non-treated, dilute acid and dilute alkaline peroxide pretreated corn stover at optimum time. After $48 \mathrm{~h}$ of time, the concentrations and yields of bioethanol were decreased by simultaneous saccharification and fermentation (SSF) process of corn stover (pretreated and non-treated) using fungi Aspergillus oryzae in the continuous stirred batch bioreactor (Figure1 and 2).

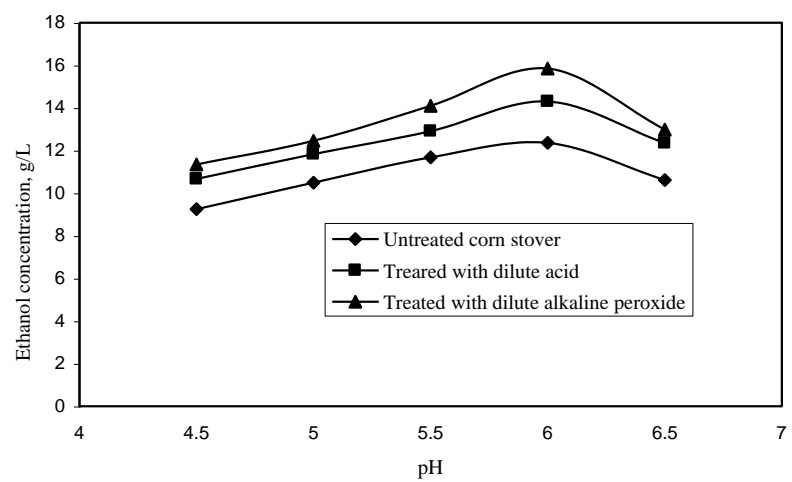

Figure 3: Effect of $\mathrm{pH}$ on Ethanol Concentration

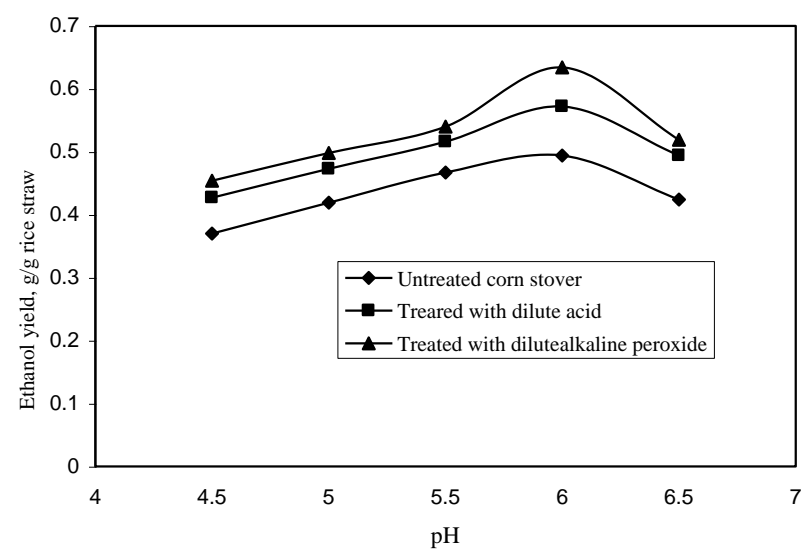

Figure 4: Effect of $\mathrm{pH}$ on Ethanol Yield

\section{Effect of pH}

The increase in concentrations and yields of bioethanol were observed with increase in $\mathrm{pH}$ upto 6.0 and then both were declined (Figure 3 and 4). Yields and concentrations of bioethanol were highest at $p \mathrm{H}$ 6.0. Maximum concentrations of bioethanol were $12.42 \mathrm{~g} / \mathrm{L}, 14.39 \mathrm{~g} / \mathrm{L}$ and $15.93 \mathrm{~g} / \mathrm{g}$ at $\mathrm{pH} 6.0$ for non-treated, dilute acid and dilute alkaline peroxide pretreated corn stover (Figure 3) respectively. Maximum yields of bioethanol were 0.496 $\mathrm{g} / \mathrm{g}, 0.578 \mathrm{~g} / \mathrm{g}$ and $0.641 \mathrm{~g} / \mathrm{g}$ of corn stover (Figure 4) at $\mathrm{pH} 6.0$ for non-treated, dilute acid and dilute alkaline peroxide pretreated corn stover respectively. Operating $\mathrm{pH}$ (6.0) was optimum for bioethanol fermentation of pretreated and non-treated corn stover with fungi Aspergillus oryzae in a continuous stirred batch bioreactor. The maximum bioethanol production were $0.259 \mathrm{~g} / \mathrm{L} \mathrm{h}$, $0.299 \mathrm{~g} / \mathrm{L} \mathrm{h}$ and $0.337 \mathrm{~g} / \mathrm{L} \mathrm{h}$ for non-treated, dilute acid and dilute alkaline peroxide pretreated corn stover at optimum $\mathrm{pH}$ respectively. With increase in $\mathrm{pH}(>6.0)$, the concentrations as well as the yields of bioethanol were sharply decreased (Figure3 and 4). Therefore, $\mathrm{pH}$ (6.0) was the optimum for bioethanol fermentation of pretreated and non-treated corn stover with fungi Aspergillus oryzae in continuous stirred batch bioreactor. When $\mathrm{pH}$ differs from the optimal value, the maintenance energy requirement of the fungi increases [27], death rate occurs, that leads to decrease in bioethanol fermentation.

\section{Effect of Temperature}

With increase in temperature, the concentrations and yields of bioethanol increased up to $50^{\circ} \mathrm{C}$ and then both were decreased (Figure 5 and 6). Yields and concentrations of bioethanol were highest at $50^{\circ} \mathrm{C}$. Maximum concentrations of bioethanol were $15.78 \mathrm{~g} / \mathrm{L}, 16.69 \mathrm{~g} / \mathrm{L}$ and $17.72 \mathrm{~g} / \mathrm{g}$ for non-treated, dilute acid and dilute alkaline peroxide pretreated corn stover at $50^{\circ} \mathrm{C}$ (Figure 5) respectively. Maximum yields of bioethanol were 0.638 $\mathrm{g} / \mathrm{g}, 0.669 \mathrm{~g} / \mathrm{g}$ and $0.714 \mathrm{~g} / \mathrm{g}$ of corn stover 
(Figure 6) at $50^{\circ} \mathrm{C}$ for non-treated, dilute acid and dilute alkaline peroxide pretreated corn stover respectively. Operating temperature $\left(50^{\circ} \mathrm{C}\right)$ was optimum for bioethanol fermentation of pretreated and non-treated corn stover with fungi Aspergillus oryzae in a continuous stirred batch bioreactor. The maximum bioethanol production were $0.330 \mathrm{~g} / \mathrm{L} \mathrm{h}, 0.351 \mathrm{~g} / \mathrm{L} \mathrm{h}$ and $0.371 \mathrm{~g} / \mathrm{L} \mathrm{h}$ for non-treated, dilute acid and dilute alkaline peroxide pretreated corn stover at optimum temperature respectively.

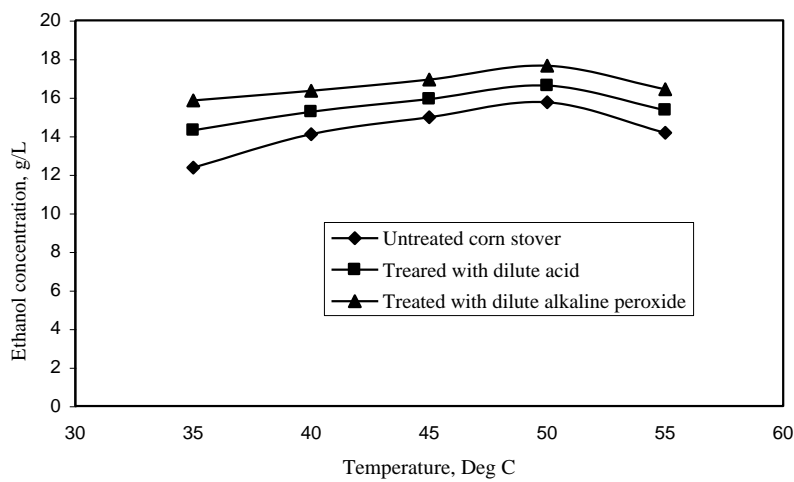

Figure 5: Effect of Temperature on Ethanol Concentration

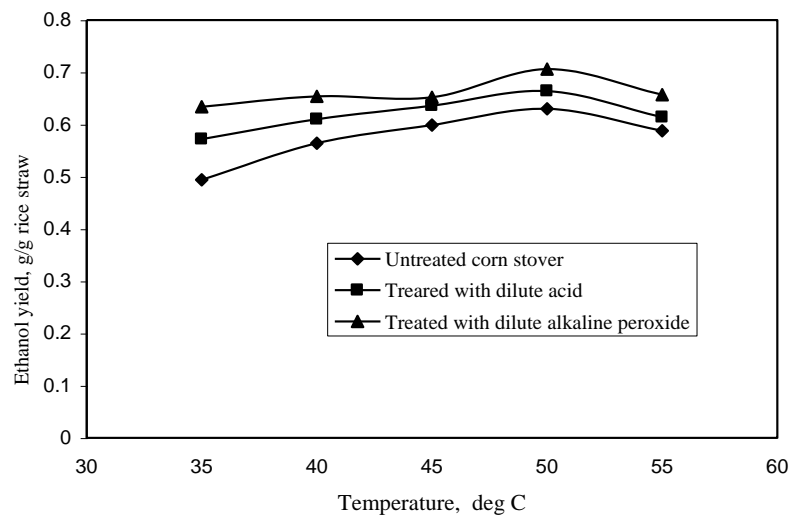

Figure 6: Effect of Temperature on Ethanol Yield

With increase in temperature $\left(>50 \quad{ }^{\circ} \mathrm{C}\right)$, yields and concentrations of bioethanol were declined (Figure 5 and 6). Temperature (50 $\left.{ }^{\circ} \mathrm{C}\right)$ was the optimum in bioethanol fermentation process of pretreated and nontreated corn stover. Temperatures below the optimum $\left(<50 \quad{ }^{\circ} \mathrm{C}\right)$ depress the rate of metabolism of fungal cells. Higher the optimal temperature $\left(>50{ }^{\circ} \mathrm{C}\right)$, the growth rate decreases and thermal death occurs. At high temperature $\left(>50{ }^{\circ} \mathrm{C}\right)$, death rate exceeds the growth rate, which causes a net decrease in the concentration of viable populations [27] of fungi Aspergillus oryzae with lower concentration of bioethanol (Figure 5 and 6).

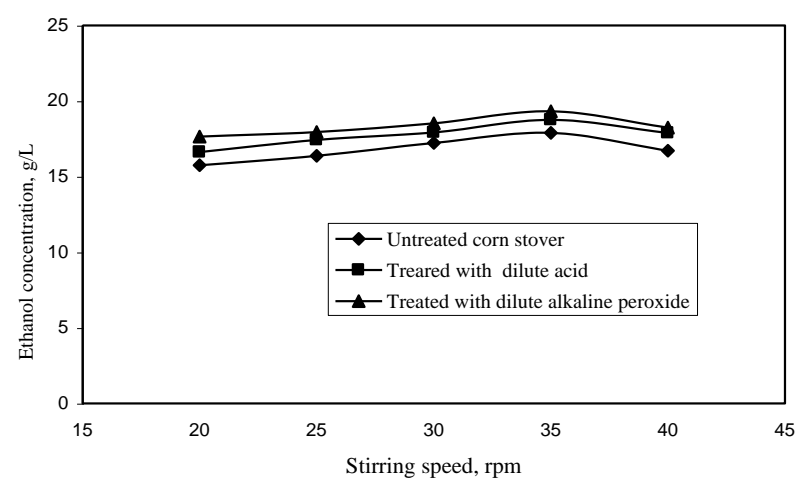

Figure 7: Effect of Stirring Speed on Ethanol Concentration

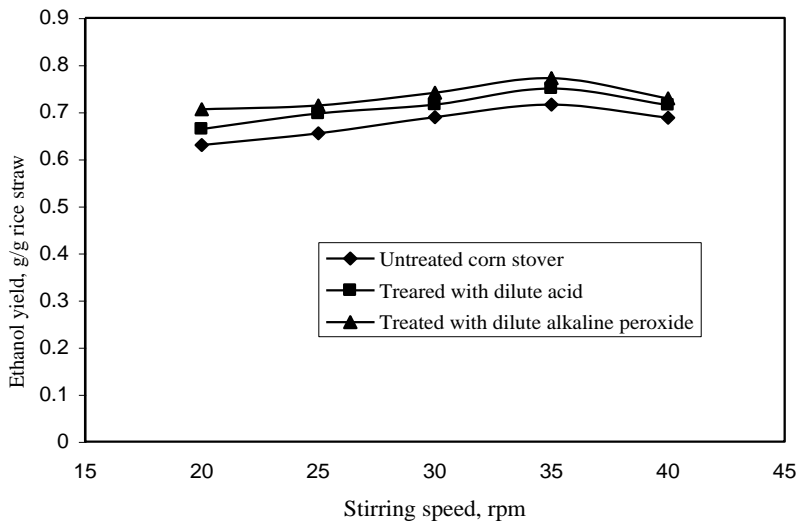

Figure 8: Effect of Stirring Speed on Ethanol Yield

\section{Effect of Stirring Speed}

With increase in stirring speed, the concentrations and yields of bioethanol increased up to $35 \mathrm{rpm}$ and then both were decreased (Figure 7 and 8). Yields and concentrations of bioethanol were highest at stirring speed of $35 \mathrm{rpm}$. Maximum 
concentrations of bioethanol were $17.95 \mathrm{~g} / \mathrm{L}$, $18.81 \mathrm{~g} / \mathrm{L}$ and $19.37 \mathrm{~g} / \mathrm{g}$ for non-treated, dilute acid and dilute alkaline peroxide pretreated corn stover at $35 \mathrm{rpm}$ (Figure7) respectively. Maximum yields of bioethanol were $0.719 \mathrm{~g} / \mathrm{g}, 0.756 \mathrm{~g} / \mathrm{g}$ and $0.775 \mathrm{~g} / \mathrm{g}$ of corn stover (Figure 8) at $35 \mathrm{rpm}$ for nontreated, dilute acid and dilute alkaline peroxide pretreated corn stover respectively. Stirring speed (35 rpm) was optimum for bioethanol fermentation of pretreated and non-treatedcorn stover with fungi Aspergillus oryzae in continuous stirred batch bioreactor. The maximum bioethanol production were $0.375 \mathrm{~g} / \mathrm{L} \mathrm{h}, 0.396 \mathrm{~g} / \mathrm{L} . \mathrm{h}$ and $0.409 \mathrm{~g} / \mathrm{L} \mathrm{h}$ for non-treated, dilute acid and dilute alkaline peroxide pretreated corn stover at $35 \mathrm{rpm}$ respectively. With increase in stirring speed $(>35 \mathrm{rpm})$, the yields and concentrations of bioethanol declined (Figure 7 and 8). Increase in stirring rates can disturb the elaborate shape of enzyme cellulase of fungi Aspergillus oryzae to such a degree that denaturation of the enzyme occurs [27] and consequently deactivation of enzymes. Therefore, the concentrations and yields of bioethanol decreased (Figure 7 and 8) with increase (>35 rpm) in stirring speed.

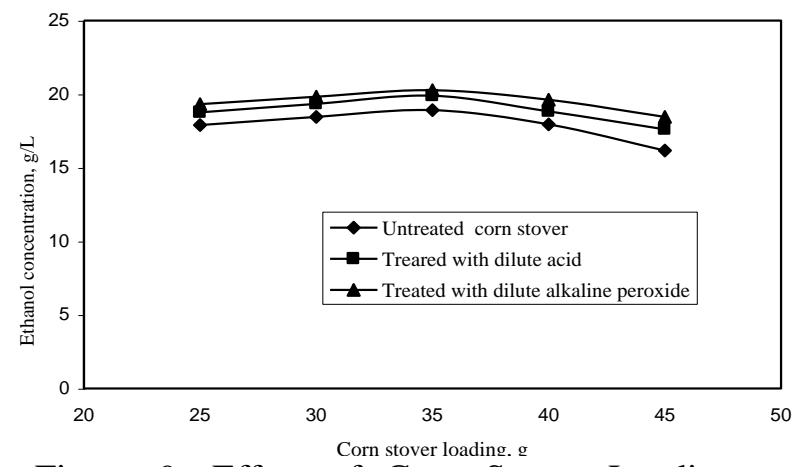

Figure 9: Effect of Corn Stover Loading on Ethanol Concentration

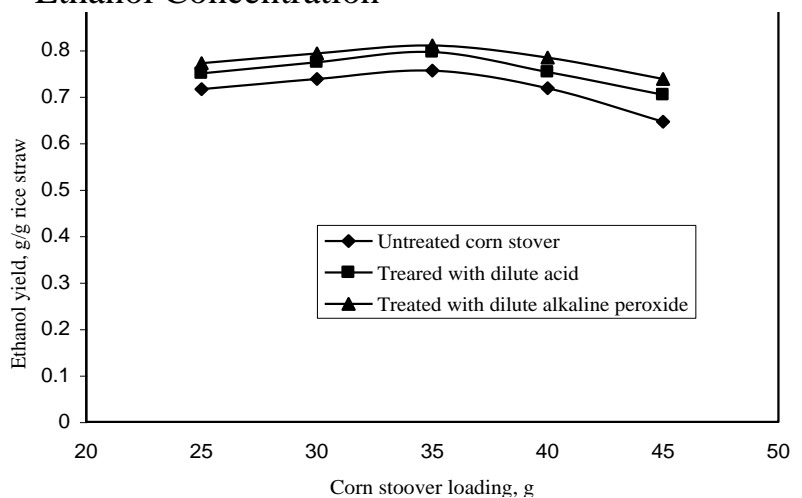

Figure 10: Effect of Corn Stover Loading on Ethanol Yield

\section{Effect of Corn Stover Loading}

With increase in loading of pretreated and non-treated corn stover, the concentrations and yields of bioethanol increased up to $35 \mathrm{~g} / \mathrm{L}$ and then both decreased (Figure 9 and 10). Maximum concentrations of bioethanol were $19.25 \mathrm{~g} / \mathrm{L}$, $19.96 \mathrm{~g} / \mathrm{L}$ and $20.51 / \mathrm{g}$ at loading $(35 \mathrm{~g} / \mathrm{L})$ for non-treated, dilute acid and dilute alkaline peroxide pretreated corn stover at optimum parameters (Figure 9) respectively. Maximum yields of bioethanol were 0.762 $\mathrm{g} / \mathrm{g}, 0.799 \mathrm{~g} / \mathrm{g}$ and $0.819 \mathrm{~g} / \mathrm{g}$ of corn stover (Figure 10) at loading of $35 \mathrm{~g} / \mathrm{L}$ for nontreated, dilute acid and dilute alkaline peroxide pretreated corn stover respectively. Loading (35 $\mathrm{g} / \mathrm{L})$ was optimum for bioethanol fermentation of pretreated and non-treated corn stover with fungi Aspergillus oryzae in a continuous stirred batch bioreactor. The maximum bioethanol production were $0.399 \mathrm{~g} / \mathrm{L} \mathrm{h}, 0.420 \mathrm{~g} / \mathrm{L} . \mathrm{h}$ and $0.431 \mathrm{~g} / \mathrm{L} \mathrm{h}$ for non-treated, dilute acid and dilute alkaline peroxide pretreated corn stover at optimum loading respectively. Low yield of bioethanol with increase in corn stover loading, can be attributed due to product and substrate (corn stover) inhibition. The bioethanol yield obtained during fermentation of lignocellulosic hydrolysates is decreased due to the presence of inhibiting compounds [16-20], such as weak acids, furans and phenolic compounds formed or released during hydrolysis.

\section{Analysis of Monod Growth Model}

The specific growth rate $(\mu=$ no. of cells/mL.s) of fungi Aspergillus oryzae for non-treated and pretreated corn stover as substrate at different loading at optimum biofuel fermentation parameters in bioreactor were calculated from respective growth data. The sp. growth rate $(\mu)$ was plotted (Figure 11) against limiting substrate 
corn stover loading to analyze Monod model [27] as shown:

$$
\mu=\mu_{\max }\left[\frac{S}{\left(K_{s}+S\right)}\right]
$$

Where, $\mathrm{K}_{\mathrm{s}}$ : Monod kinetic parameter at which the sp. growth rate $(\mu)$ is half of maximum growth rate $\mu$ max i.e. $\mu=\mu_{\max } / 2$, at $\mathrm{K}_{\mathrm{s}}=\mathrm{S}$ (upto linear portion of the curve). The model indicated a division between the lower concentration range [26], where $\mu$ is strongly (linearly) dependent on $\mathrm{S}$, and the higher concentration range, where $\mu$ becomes independent of $S$ (curve portion of Figure 11). Here, S: Loading of the limiting substrate corn stover.

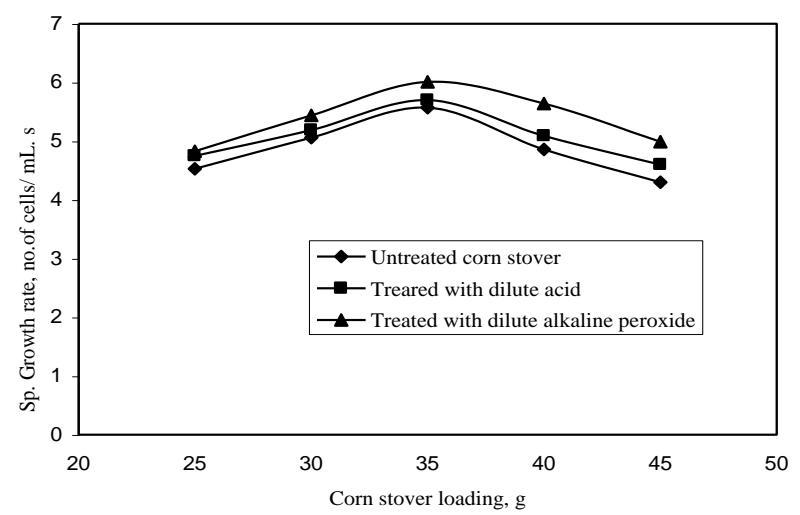

Figure 11: Monod Model for sp. Growth Rate

With increase in pretreated and nontreated corn stover loading, the sp. growth of fungi Aspergillus oryzae increased, and then it decreased (Figure 11) due to substrate and product inhibition effect [27]. The sp. growth rate $(\mu)$ were $5.30 \mathrm{~s}^{-1}, 5.54 \mathrm{~s}^{-1}$, and $5.93 \mathrm{~s}^{-1}$ (upto linear portion of Figure 11) and maximum sp. growth rate $\left(\mu_{\max }\right)$ were $10.60 \mathrm{~s}^{-1}, 11.08 \mathrm{~s}^{-1}$ and $11.86 \mathrm{~s}^{-1}$ using Monod model for non-treated, dilute acid and dilute alkaline peroxide pretreated corn stover respectively. The Monod kinetic parameter $\left(\mathrm{K}_{\mathrm{s}}\right)$ were $33.87 \mathrm{~g} / \mathrm{L}, 34.21 \mathrm{~g} / \mathrm{L}$ and $34.85 \mathrm{~g} / \mathrm{L}$ for non-treated, dilute acid and dilute alkaline peroxide pretreated corn stover respectively (Figure 11).

An important case of inhibition of fungal (Aspergillus oryzae) growth is that of product bioethanol and substrate concentration [27]. The utilization pattern of substrate corn stover is significantly influenced by adaptation characteristics of fungal culture. Adaptation of fungi significantly affects the sp. growth rate, length of lag-phase and overall fermentation of bioethanol. Though the fermentation media contained many numbers of sugars (hydrolysis products of corn stover like hexoses and pentoses ), fungi does not show diauxic behavior, where, the presence of two or more carbon source, fungi utilize preferential one upto exhausted, then utilize second or other carbon source. It does not utilize both carbon sources at a time. The diauxic substrate inhibition has a depression effect on fungal growth rate and bioethanol fermentation (curve portion of Figure 11). Depending on the type of lignocellulosic material the composition of inhibitors will differ and their influence on the fungi and the fermentation performance will consequently vary [15-18]."

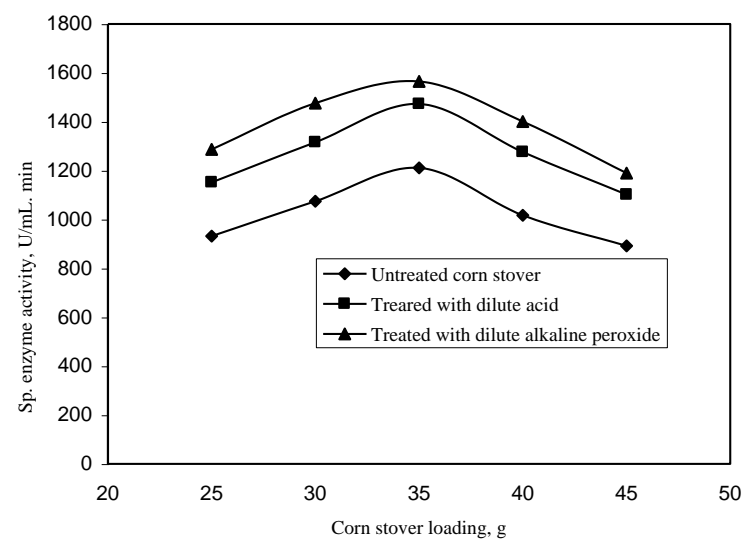

Figure 12: Michaelies-Menten Kinetic Model for sp. Enzyme Activity 


\section{Analysis of Michaelis-Menten Enzyme Kinetic Model}

The cellulase enzyme activity of fungi in the presence of non-treated, dilute acid and dilute alkaline peroxide pretreated corn stover at different loading at optimum fermentation conditions is shown in Figure 12. For analysis of Michaelis-Menten Enzyme kinetic model, specific enzyme activity $(v=$ Units $/ \mathrm{mL}$. min $)$ is plotted against limiting substrate pretreated and non-treated corn stover loading by using Michaelis-Menten Enzyme Kinetic Model [27] as given:

$$
v=v_{\max }\left[\frac{S}{\left(K_{m}+S\right)}\right]
$$

Where, $\mathrm{K}_{\mathrm{m}}$ : an intrinsic kinetic parameter, where the limiting substrate concentration at which the specific enzyme activity $(v)$ is half of maximum specific activity i.e. $v=v$ $\max / 2$, at $\mathrm{K}_{\mathrm{m}}=\mathrm{S}$. The model indicates a division between the lower concentration range, where $v$ is strongly (linearly) dependent on $\mathrm{S}$, and the higher concentration range, where $v$ becomes independent of S. $v_{\max }$ is solely a function of rate parameters. Here, $\mathrm{S}$ is the limiting substrate corn stover concentration.

With increase in pretreated and nontreated corn stover loading, the specific enzyme activity $(v)$ of cellulase from fungi Aspergillus oryzae was increased, and then it was decreased due to substrate and product inhibition effect. Some enzymes (cellulases) are produced at all from fungi, whereas others are influenced by substrate. The repression and depression processes allow fungi Aspergillus oryzae to regulate their enzyme content in direct response to the environment [27]. The sp. enzyme activity (v) were $1192 \mathrm{~min}^{-1}, 1463 \mathrm{~min}^{-1}$ and $1559 \mathrm{~min}^{-1}$ (upto linear portion of
Figure 12) and maximum sp. growth rate ( $v$ max) were $2384 \mathrm{~min}^{-1}, 2926 \mathrm{~min}^{-1}$ and 3118 $\min ^{-1}$ using Michaelis-Menten enzyme kinetic model for non-treated, dilute acid and dilute alkaline peroxide pretreated corn stover respectively. The Michaelis-Menten parameter $\left(\mathrm{K}_{\mathrm{m}}\right)$ were $34.42 \mathrm{~g} / \mathrm{L}, 34.63 \mathrm{~g} / \mathrm{L}$ and $34.85 \mathrm{~g} / \mathrm{L}$ for non-treated, dilute acid and dilute alkaline peroxide pretreated corn stover respectively.

\section{Kinetic Analysis of Batch Bioreactor}

The kinetics of aerobic bioethanol fermentation of non-treated, dilute acid and dilute alkaline peroxide pretreated corn stover in continuous stirred batch bioreactor using fungi Aspergillus oryzae was investigated (Figure 13). The first order rate equation [28] as shown:

$$
-\ln (1-\mathrm{X})=\mathrm{kt}
$$

Here, X: Corn stover conversion at time $\mathrm{t}$

A straight line (Figure 13) was obtained by plotting fermentation time $(\mathrm{t})$ against $\left[-\ln \left(\mathrm{X} / \mathrm{X}_{0}\right)\right.$. The kinetic rate constants (k) were measured from Figure13. The kinetic rate constants $(\mathrm{k})$ were $0.014 \mathrm{~h}^{-1}$ , $0.016 \mathrm{~h}^{-1}$ and $0.019 \mathrm{~h}^{-1}$ for non-treated, dilute acid and dilute alkaline peroxide pretreated corn stover respectively. Hence, bioethanol fermentation from corn stover was good agreement with the first order rate kinetics [28].

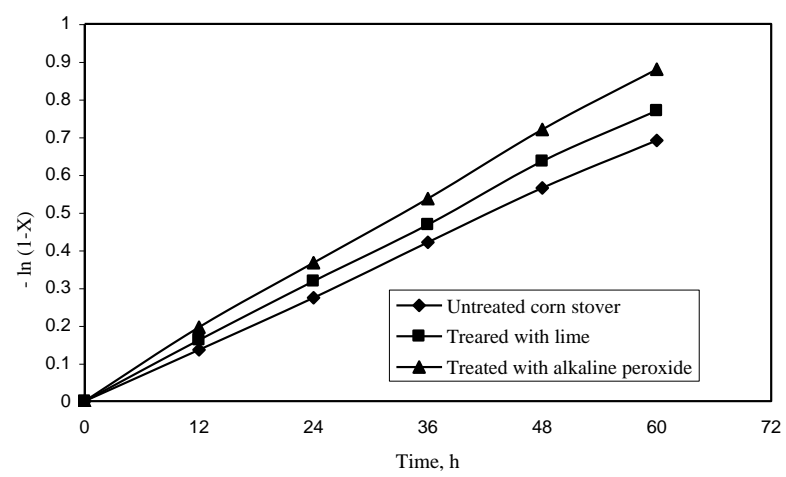

Figure 13: Rate Kinetics of Bioethanol Fermentation in Batch Reactor 


\section{CONCLUSION}

Fermentation of bioethanol from pretreated and non-treated corn stover with fungi Aspergillus oryzae in a continuous stirred batch bioreactor was an effective biofuel production process. The optimum parameters for bioethanol fermentation were: time, $48 \mathrm{~h}$; $\mathrm{pH}, 6.0$; temperature, $50^{\circ} \mathrm{C}$; stirring speed, $35 \mathrm{rpm}$; and corn stover loading, $\quad 35 \mathrm{~g} / \mathrm{L}$. The maximum concentration of bioethanol at optimum fermentation process parameters were 0.762 $\mathrm{g} / \mathrm{g}, 0.799 \mathrm{~g} / \mathrm{g}$ and $0.819 \mathrm{~g} / \mathrm{g}$ for non-treated, dilute acid and dilute alkaline peroxide pretreated corn stover respectively. Maximum yields of ethanol were $0.399 \mathrm{~g} / \mathrm{L}$ $\mathrm{h}, 0.420 \mathrm{~g} / \mathrm{L} . \mathrm{h}$ and $0.431 \mathrm{~g} / \mathrm{L} \mathrm{h}$ of corn stover at optimum parameters for nontreated, dilute acid and dilute alkaline peroxide pretreated corn stover respectively. The sp. growth rate $(\mu)$ were $5.30 \mathrm{~s}^{-1}, 5.54$ $\mathrm{s}^{-1}$, and $5.93 \mathrm{~s}^{-1}$ and maximum $\mathrm{sp}$. growth rate $\left(\mu_{\max }\right)$ were $10.60 \mathrm{~s}^{-1}, 11.08 \mathrm{~s}^{-1}$ and $11.86 \mathrm{~s}^{-1}$ using Monod model for nontreated, dilute acid and dilute alkaline peroxide pretreated corn stover respectively. The Monod parameter $\left(\mathrm{K}_{\mathrm{s}}\right)$ were $33.87 \mathrm{~g} / \mathrm{L}, 34.21 \mathrm{~g} / \mathrm{L}$ and $34.85 \mathrm{~g} / \mathrm{L}$ for non-treated, dilute acid and dilute alkaline peroxide pretreated corn stover respectively. The sp. enzyme activity (v) were 1192 $\min ^{-1}, 1463 \mathrm{~min}^{-1}$ and $1559 \mathrm{~min}^{-1}$ and maximum sp. growth rate $\left(v_{\max }\right)$ were 2384 $\min ^{-1}, 2926 \mathrm{~min}^{-1}$ and $3118 \mathrm{~min}^{-1}$ using Michaelis-Menten enzyme kinetic model for non-treated, dilute acid and dilute alkaline peroxide pretreated corn stover respectively. The Michaelis-Menten parameter $\left(\mathrm{K}_{\mathrm{m}}\right)$ were $34.42 \mathrm{~g} / \mathrm{L}, 34.63 \mathrm{~g} / \mathrm{L}$ and $34.85 \mathrm{~g} / \mathrm{L}$ for non-treated, dilute acid and dilute alkaline peroxide pretreated corn stover respectively. The first order rate constants (k) were $0.014 \mathrm{~h}^{-1}, 0.016 \mathrm{~h}^{-1}$ and $0.019 \mathrm{~h}^{-1}$ for non-treated, dilute acid and dilute alkaline peroxide pretreated corn stover respectively.

\section{REFEENCES}

[1] Lampley, J, Moo-Young, M. and Sullivan, H F , Bioenergy, Desai, A. V. (Ed), Wiley Eastern Ltd, International Development Research Centre, Ottawa, Japan, 1990. pp. 6

[2] Sánchez, Ó J and Cardona, C A, Bioresource Technology, 2008. 99 (13): pp. 5270-5277.

[3] Park, I., Kim, I., Kang, K, Sohn, H., Rhee, I., Jin, I and Jang, H, Process Biochemistry, 2010. 45 (4): pp. 487 - 496.

[4] Christakopoulos, P, Macris, B J, and Kekos, D, Enzyme Microbial Technology, 1989. 11(4), p. 236-345.

[5] Christakopoulos, P., Koullas, D. P., Kekos, D, Koukios, E G., and Macris, B J, Bioresource Technology, 1991. 35( 3): pp. 297-304.

[6] Ghosh, P, Pamment, N B and Martin, W $R$ B, Enzyme Microbial Technology, 1982. 4 (6), pp. $425-436$.

[7] Brethauer, $S$ and Wyman, $C E$, Bioresource Technology, 2010. 101 (13): pp. 4862-4872.

[8] Wyman, C E, Spindler, D D, and Grohmann, K., Biomass Bioenergy, 3( 5), p. 301 (1992).

[9] Chen, H, Han, Y and Xu, J, Process Biochemistry, 2008. 43(12): pp. 1462-1470. [10] Hari Krishna, S, Prasanthi, K, Chowdary, $G V$ and Ayyanna, C, Process Biochemistry, 1998. 33 ( 8): pp. 825.

[11] Hernández-Salas , J M, Villa-Ramírez, $M S, \quad V e l o z-R e n d o ́ n, \quad J S$, RiveraHernández, $K N$, González-César, $R$ A., Plascencia-Espinosa, $M A$ and TrejoEstrada, $S R, \quad$ Bioresource Technology, 2009. 100( 3): pp. 123-130.

[12] Sassner, P, Galbe, $M$ and Zacchi, G, Biomass Bioenergy, 2008. 32 ( 5): pp. 422430. 
[13] Öhgren, A R, Galbe, $M$ and Zacchi, $G$ , Biomass Bioenergy, 2006. 30 (10): pp. 863-871.

[14] Hahn-Hägerdal, B, Galbe, $M$, Gorwa-Grauslund, $M F$, Lidén, $G$ and Zacchi, G, Trends in Biotechnology, 2006. 24 ( 12): pp. 549-558.

[15] Linde, M , Jakobsson, E-L, Galbe, M and Zacchi , G, Biomass Bioenergy, 2008. 32( 4): pp. 326-335.

[16] Hendriks, $T W M$. and Zeeman, G, Bioresource Technology, 2009. 100 (1): pp. $10-19$.

[17] Saha, B C and Cotta, M A, Enzyme Microbial Technology, 2007. 41 ( 4): pp. 528536.

[18] Saha, B C and Cotta, M A, Biomass Bioenergy, 2008. 32 (10): pp. 971-980.

[19] Saha, B C and Cotta, $M A$, New Biotechnology, 2010. 27 ( 1): pp. 10-18. [20] Kootstra, A M J, Beeftink., H H, Scott, $E L$, and Sanders, J P M, Biochemical Engineering Journal., 2009. 46 (2): pp 126134.

[21] Talebnia, F, Karakashev, D, and Angelidaki, I, Bioresource Technology, 2010. 101 (13): pp. 4744 -4750.

[22] Yamane, Y-I, Fujita, J, Izuwa, S, Fukuchi, K, Shimizu, R-I, Hiyoshi., A , Fukuda., H, Mikami, S, Kizaki, Y, and Wakabayashi, $S$, Journal Bioscience Bioengineering, 2002.93 (5): pp. 479-487.

[23] Hossain, $S M$, and Das, $M$, Indian Chemical Engineer, 2001. 43(3): pp. 180 186.

[24] Hossain, S M, Das, $M$, and Ibrahim, $S$ H, Indian Journal Chemical Technology, 2002. 9(3), pp. 227-234.

[25] Hossain, $S M$ Das, $M$, Ibrahim, $S H$, and Anantharaman, N, Jounal of Current Science, 2002. 2(1): 279-286 .

[26] Trivedy, $R K$, and Goel, $P K$, Chemical and Biological Methods for Water Pollution Studies, Environmental Publications, Karad, India, 1985.
[27] Pclczar, M J, Chan, E C S, and Kring, $N R$, Microbiology, 5th edn, Tata McGrawHill Publishing Co Ltd, New Delhi, India, 2004.

[28] Levenspiel, $O$, Chemical Reaction Engineering, 3rd edn, John Willey \& Sons, Inc, New York, U S A, 1999. 